KLeczkowski, J. \& KLeczkowski, A. (1953). J. gen. Microbiol. 8, 135-144.

\title{
The Behaviour of Rhizobium Bacteriophages during and after Exposure to Ultraviolet Radiation
}

\author{
BY J. KLECZKOWSKI AND A. KLECZKOWSKI \\ Rothamsted Experimental Station, Harpenden, Hertfordshire
}

SUMMARY: After inactivation by ultraviolet radiation, particles of two Rhizobium bacteriophages interfered temporarily with the multiplication of active particles of the homologous phage, in liquid cultures of their respective host bacteria. Inactivated particles did not affect the number of plaques produced by active particles in bacterial cultures on agar.

No evidence was found that particles that were inactive singly became active when two or more of them infected the same bacterial cell.

The rate of inactivation approximated closely to that of a first-order reaction. Exposing infected bacteria to visible light increased the residual activities of irradiated phage preparations by amounts equivalent to decreasing the doses of ultraviolet irradiation by a constant factor. Exposing either the irradiated phage preparations or the bacterial cultures separately to visible light had no effect.

Those ultraviolet irradiated phage particles which remained active were so altered that they became relatively unstable.

Much work has been done on the effects of ultraviolet radiation on bacteriophages of Bacterium coli, but relatively little on others. The course of inactivation, i.e. of becoming unable to multiply and cause lysis, was found to approximate to that of a first-order reaction, though slight deviations have been recorded (Latarjet \& Wahl, 1945; Latarjet \& Morenne, 1951). Some inactivated phages have proved able to interfere with multiplication of host bacteria and of active phages (Luria \& Delbrück, 1942). Residual activity of some irradiated phage preparations could be increased by increasing their concentration at which they were brought into contact with susceptible bacteria ('multiplicity reactivation' Luria \& Dulbecco, 1949) or by exposure of infected host bacteria to visible light ('photo-reactivation' Dulbecco, 1950).

The work described in the present paper was started to see how far these phenomena applied to bacteriophages of strains of Rhizobium and was done simultaneously with a comparable work on plant viruses (Bawden \& Kleczkowski, 1953). During the work a new phenomenon was encountered; when irradiated phage preparations were stored their residual activity decreased at a much higher rate than did the activity of unirradiated phage preparation stored in the same conditions. A few experiments were made to study some details of this phenomenon.

\section{MATERIAL AND METHODS}

Two strains, 317 and $\mathrm{Cl}_{5}$, of pea and clover nodule bacteria, respectively, and their two homologous bacteriophages, 317 and $\mathrm{Cl}_{5}$, were used. Each bacteria strain was lysed by its homologous phage but not by the other. The bacterial strains, the bacteriophages, media and the 'poured plate' method of 
producing plaques, have been described previously (Kleczkowska, 1945; Kleczkowski \& Kleczkowski, 1952). Phage cultures were lysed liquid bacterial cultures passed through a Chamberland L3 filter and stored at $2^{\circ}$.

The source of ultraviolet (u.v.) radiation was a low-pressure mercury discharge lamp made by the Thermal Syndicate Ltd. and fitted with a cylindrical chromium-plated reflector. According to the makers' specifications the intensity of radiation, $99 \%$ of which was of wave-length $2536 \mathrm{~A}$, was $121 \mu \mathrm{W}$./sq.cm. at a distance of $100 \mathrm{~cm}$.

Undiluted phage cultures were irradiated as layers $0.15 \mathrm{~cm}$. deep in a Petri dish. They were exposed to the lamp at a distance of $20 \mathrm{~cm}$. and rocked during the whole time of exposure. The rocking is assumed to have ensured that all phage particles were equally exposed to the radiation.

The intensity of radiation and its absorption by irradiated materials were not measured. The measurements would be useless because the amount of absorption by phage particles, as distinct from that caused by other constituents of crude bacterial lysates, would still remain unknown.

\section{RESULTS}

\section{Interference by inactivated phage with multiplication of active phage and of host bacteria}

This problem is considered first because if there were any interference it might need to be allowed for whenever residual activity of an irradiated phage preparation is tested.

The presence of inactivated phage does not interfere with formation of plaques by active phage. This is shown by the fact that adding untreated phage to an irradiated phage preparation, which is then incubated suitably diluted in a culture of host bacteria and plated, has no effect on the number of plaques. Nor is the plaque number affected by adding an irradiated phage preparation to an equal volume of a culture of host bacteria in which untreated phage preparation is then diluted and plated. Thus no active phage particles are destroyed or otherwise made permanently unable to multiply. On the other hand, irradiated phage preparations can stop completely, though temporarily, the multiplication of active phage in liquid cultures of host bacteria and can make the host bacteria unable to multiply and form colonies on agar medium.

Table 1 shows that an irradiated preparation of phage 317 prevented the multiplication of active phage $\mathbf{3 1 7}$ for at least $3 \mathrm{hr}$., during which the phage concentration of the control increased 30 times. However, this was so only when the irradiated phage preparation was added undiluted to an equal volume of a $24 \mathrm{hr}$. bacterial culture, i.e. when the number of inactive phage particles in the final mixture was more than 35 times that of the number of bacteria and 500,000 times that of the number of active phage particles. When the concentration of the irradiated phage preparation was decreased to onequarter, phage multiplication was not completely inhibited and there was no inhibition when the concentration was decreased to one-sixteenth. 
After $24 \mathrm{hr}$. incubation, the concentration of active phage in the culture containing even the most concentrated irradiated phage was almost as high as that of the control. It is obvious, therefore, that the inhibitory effect of the irradiated phage preparation lasted less than $24 \mathrm{hr}$.

Table 1. Effect of an ultraviolet-irradiated preparation of phage 317 on multiplication of phage $\mathbf{3 1 7}$

Materials. Untreated preparation of 317 phage: $5 \times 10^{8}$ plaques $/ \mathrm{ml}$. U.v. irradiated preparation of 317 phage: irradiation time was $20 \mathrm{~min}$; activity fell from $5 \times 10^{8}$ to 50 plaques $/ \mathrm{ml}$. U.v. irradiated preparation of $\mathrm{Cl}_{5}$ phage: irradiation time was $20 \mathrm{~min}$.; activity fell from $18 \times 10^{8}$ to 80 plaques $/ \mathrm{ml}$. $24 \mathrm{hr}$. culture of 317 bacteria: $15 \times 10^{6}$ cells/ml. (haemocytometer count). U.v. irradiated medium: irradiation time was $20 \mathrm{~min}$.

\begin{tabular}{|c|c|c|c|}
\hline \multirow{2}{*}{$\begin{array}{l}\text { The mixtures: } 24 \mathrm{hr} \text {. culture of } \\
\mathbf{3 1 7} \text { bacteria }+ \text { an equal volume of: }\end{array}$} & \multicolumn{3}{|c|}{$\begin{array}{l}\text { Phage concentration in the mixtures } \\
\text { (in terms of numbers of plaques } / \mathrm{ml} \text {.) }\end{array}$} \\
\hline & Immediately & After $3 \mathrm{hr}$. & After $24 \mathrm{hr}$. \\
\hline Irradiated 317 phage (undiluted) & 530 & 460 & $39 \times 10^{8 *}$ \\
\hline Irradiated 317 phage (dil. $1 / 4 \dagger$ ) & 600 & 1,500 & - \\
\hline Irradiated 317 phage (dil. $1 / 16 \dagger$ ) & 550 & 19,000 & - \\
\hline Irradiated $\mathrm{Cl}_{6}$ (undiluted) & 560 & 7,500 & $52 \times 10^{8}$ \\
\hline Untreated $\mathrm{Cl}_{5}$ (undiluted) & 500 & 15,000 & $54 \times 10^{8}$ \\
\hline Irradiated medium & 570 & 8,000 & $50 \times 10^{8}$ \\
\hline Untreated medium & 550 & 16,500 & $53 \times 10^{8}$ \\
\hline
\end{tabular}

One volume of the untreated preparation of 317 phage diluted $1 / 10^{5}$ was added to nine volumes of each mixture. Samples of the mixtures were taken for assay of concentration of phage 317 by the plaque count method immediately, after $3 \mathrm{hr}$. and after $24 \mathrm{hr}$. incubation at $\mathbf{2 5}^{\circ}$.

* The mean diameter of the plaques was about half that of the control.

$\uparrow$ Diluted in untreated medium.

Although after $24 \mathrm{hr}$. incubation the culture containing irradiated phage produced almost as many plaques as did the control phage culture, the diameter of the plaques (mean $=1.9 \mathrm{~mm}$.) was smaller than that of the control (mean $=3 \cdot 4 \mathrm{~mm}$.). No explanation of this phenomenon can be offered. It is not caused by a phage mutation, because phage isolated from the small plaques produced plaques of normal size.

Table 2 shows that u.v. inactivated phage $\mathrm{Cl}_{5}$ also temporarily prevented the multiplication of active phage $\mathrm{Cl}_{5}$ in a liquid culture of $\mathrm{Cl}_{5}$ bacteria. Comparison of Tables 1 and 2 shows that the multiplication of active phage was prevented only by irradiated preparations of the homologous phage. Irradiated preparations of the other inhibited only to the same extent as did the irradiated medium.

This apparent specificity probably occurs because each of the two bacterial strains was susceptible to only one of the two phages used. Luria \& Delbrück (1942), who used one bacterial host susceptible to two different phages, found that irradiated preparations of one phage could slow the multiplication of either phage in liquid cultures of their common host, whereas irradiated preparations of the other had no effect on multiplication of either. It appears, therefore, that if a u.v. irradiated phage can interfere with the multiplication 
of active phage, it does so only in a bacterial strain which is its host and then it interferes with the multiplication of any phage in it.

Luria \& Delbrück (1942) found that the u.v. inactivated phage that interfered with phage multiplication also rendered the bacteria unable to multiply, whereas the other inactivated phage had no such effect. Moreover, the ability of the irradiated phage to interfere with phage multiplication could be destroyed by excess of u.v. irradiation, when their ability to make their host

\section{Table 2. Effect of an ultraviolet irradiated preparation of $\mathrm{Cl}_{5}$ phage on multiplication of $\mathrm{Cl}_{5}$ phage}

Materials. Untreated preparation of $\mathrm{Cl}_{5}$ phage: $18 \times 10^{8}$ plaques $/ \mathrm{ml}$. U.v. irradiated preparation of $\mathrm{Cl}_{5}$ phage: irradiation time was $20 \mathrm{~min}$; activity fell from $18 \times 10^{8}$ to 80 plaques/ml. U.v. irradiated preparation of 317 phage: irradiation time was 20 min.; activity fell from $5 \times 10^{8}$ to 50 plaques $/ \mathrm{ml}$. $24 \mathrm{hr}$. culture of $\mathrm{Cl}_{5}$ bacteria: $16 \times 10^{6} \mathrm{cells} / \mathrm{ml}$. (haemocytometer count). U.v. irradiated medium: irradiation time was $20 \mathrm{~min}$.

\begin{tabular}{|c|c|c|}
\hline \multirow{2}{*}{$\begin{array}{l}\text { The mixtures: } 24 \mathrm{hr} \text {. culture of } \\
\mathrm{Cl}_{5} \text { bacteria }+ \text { an equal volume of: }\end{array}$} & \multicolumn{2}{|c|}{$\begin{array}{l}\text { Phage concentration in the mixture } \\
\text { (in terms of numbers of plaques } / \mathrm{ml} \text {. }\end{array}$} \\
\hline & Immediately & After 5 hr. \\
\hline Irradiated phage $\mathrm{Cl}_{5}$ & 950 & 810 \\
\hline Irradiated phage 317 & 890 & 2500 \\
\hline Untreated phage 317 & 930 & 6700 \\
\hline Irradiated medium & 860 & 3000 \\
\hline Untreated medium & 870 & 7000 \\
\hline
\end{tabular}

One volume of the untreated preparation of $\mathrm{CI}_{5}$ phage diluted $1 / 10^{5}$ was added to nine volumes of each mixture. Samples of the mixtures were taken for assay of concentration of phage $\mathrm{Cl}_{5}$ by the plaque count method immediately and after $5 \mathrm{hr}$. incubation at $\mathbf{2 5}^{\circ}$.

bacteria unable to multiply also disappeared. It is probable, therefore, that the interference with both phage and host multiplication are expressions of the same disturbance of host metabolism caused by the u.v. inactivated phage. If so, u.v. inactivated Rhizobium phages would be expected to be able to interfere with multiplication of their host bacteria, and Table 3 shows that addition of an irradiated preparation of phage 317 to an equal volume of a $24 \mathrm{hr}$. culture of 317 bacteria did decrease considerably the number of colonies formed by the bacteria on agar medium. The decrease was probably caused by u.v. inactivated phage and not by the remaining active phage or by some other constituent of the irradiated phage preparation. The number of plaques formed by the irradiated preparation was $50 / \mathrm{ml}$. Thus, if the proportion of active phage particles that formed plaques when the preparation was assayed was $1 / m$, the number of active phage particles per ml. of the mixture with the bacterial culture was $25 \mathrm{~m}$. The results of an electron microscopic study by Luria, Williams \& Backus (1951) suggest that the value of $m$ is not greater than 10, so that the number of active phage particles per $\mathrm{ml}$. of the mixture with bacterial culture was probably not greater than 250 , whereas the approximate number of bacterial cells per $\mathrm{ml}$. of the mixture rendered unable to form colonies was $1 \times 10^{6}$. Therefore, some constituent of the irradiated preparation other than active phage must have made them unable 
to do so. The fact that irradiated medium or irradiated (as well as unirradiated) preparations of a heterologous phage $\left(\mathrm{Cl}_{5}\right)$ caused no drop in the number of colonies, shows that the constituent of the irradiated preparation of the homologous phage (317) that caused the drop was probably inactivated phage $\mathbf{3 1 7}$.

\section{Table 3. Effect of an ultraviolet irradiated preparation of phage $\mathbf{3 1 7}$} on multiplication of its host bacteria

\begin{tabular}{|c|c|c|}
\hline \multirow{2}{*}{$\begin{array}{l}\text { The mixtures : } 24 \text { hr. culture of } \\
317 \text { bacteria + an equal volume of: }\end{array}$} & \multicolumn{2}{|c|}{$\begin{array}{l}\text { Mean numbers of colonies/plat } \\
\text { formed by the mixtures used } \\
\text { at a dilution of }\end{array}$} \\
\hline & $1 / 10^{4}$ & $1 / 10^{5}$ \\
\hline Untreated phage 317 & 42 & $4 \cdot 5$ \\
\hline Irradiated phage $\mathbf{3 1 7}$ & 264 & $\mathbf{2 5}$ \\
\hline Untreated phage $\mathrm{Cl}_{5}$ & 380 & 42 \\
\hline Irradiated phage $\mathrm{Cl}_{5}$ & 370 & 39 \\
\hline Untreated medium & $\mathbf{3 5 5}$ & 36 \\
\hline Irradiated medium & 363 & 39 \\
\hline
\end{tabular}

The mixtures were incubated for $15 \mathrm{~min}$. at room temperature then diluted $1 / 10^{4}$ and $1 / 10^{5}$ in untreated medium, and $1 \mathrm{ml}$. of each dilution was plated by mixing with $9 \mathrm{ml}$. of melted agar medium cooled to $42^{\circ}$ and pouring into a Petri dish which was then incubated for 7 days at $25^{\circ}$. There were four replications of each treatment.

However, irradiated medium or irradiated preparations of the heterologous phage can slow bacterial multiplication in liquid cultures if mixed in equal volumes. This agrees with other observations that u.v. irradiation makes media less suitable for bacterial growth, an effect usually attributed to the action of peroxides formed by u.v. irradiation (Coblenz \& Fulton, 1924; Bedford, 1927; Proks, 1933; Wyss, Haas, Clark \& Stone, 1950). The slight inhibitory effect on phage multiplication given by irradiated medium and irradiated preparations of heterologous phages (Tables 1 and 2) probably resulted from their effect on growth of the host bacteria.

The common feature of the effect of u.v. inactivated phages, on the one hand, and of such inhibitors as ribonuclease or some polysaccharides (Kleczkowski \& Kleczkowski, 1952), on the other, is that they interfere with phage multiplication in liquid cultures of host bacteria while having no effect on the numbers of plaques formed on agar. This effect on the former and not the latter, showing an apparent contradiction, has been discussed elsewhere (Kleczkowski \& Kleczkowski, 1952).

\section{Tests for ' multiplicity reactivation'}

The 'multiplicity reactivation' observed with a few coli bacteriophages (Luria \& Dulbecco, 1949) was not observed with the Rhizobium bacteriophages used in this work. The numbers of plaques produced by u.v. irradiated preparations of these phages did not increase with the increasing concentration at which they were brought into contact with host bacteria before plating. The phenomenon of 'multiplicity reactivation' does not seem to be very common. It 
was observed only in a proportion of a few coli phages tested by Luria \& Dulbecco (1949), and it could not be observed with a Staphylococcus phage (Price, 1950), or with three different plant viruses (Bawden \& Kleczkowski, 1953).

\section{The rate of inactivation and the effect of visible light}

Table 4 shows that the rate of inactivation of the 317 phage by u.v. radiation approximates closely to that of a first-order reaction because the value of $k$, obtained from the equation $p=e^{-k t}$ (where $p$ is the proportion of remaining activity and $t$ the time of exposure), was almost constant when experimental conditions were constant.

\section{Table 4. The rate of inactivation of phage 317}

Time of

$\begin{array}{ccc}\begin{array}{c}\text { exposure to } \\ \text { u.v. radiation } \\ \text { (min.) }\end{array} & \begin{array}{c}\text { Dilution at which } \\ \text { the preparation } \\ \text { was plated }\end{array} & \begin{array}{c}\text { Total nos. of } \\ \text { plaques formed on } \\ \text { 14 plates* }\end{array} \\ 0 & 1 / 1^{8} & 519 \\ 0 \cdot 283 & 1 / 1^{8} & 278 \\ 1 & 1 / 10^{7} & 498 \\ 2 & 1 / 1^{8} & 713 \\ 4 & 1 / 0^{4} & 956\end{array}$

$\begin{array}{lc}\begin{array}{c}\text { Proportion of } \\ \text { remaining } \\ \text { activity }\end{array} & k \dagger \\ 1 \cdot 00 & - \\ 0 \cdot 54 & \mathbf{2 \cdot 1 5} \\ 0 \cdot 096 & 2 \cdot 34 \\ 0 \cdot 014 & 2 \cdot 13 \\ 0 \cdot 00018 & \mathbf{2 \cdot 1 6}\end{array}$

* There were seven separate experiments with the same times of exposure. In each experiment two platings were made with each preparation giving 14 as the total number of platings.

$\dagger$ The value of $k$ is obtained from the equation $p=e^{-k t}$, where $p$ is the proportion of remaining activity and $t$ is the time of exposure (in minutes).

Table 5. The effect of visible light on the activity of ultraviolet irradiated 317 phage

\begin{tabular}{|c|c|c|c|c|c|c|c|}
\hline \multirow[b]{2}{*}{$\begin{array}{l}\text { Time of } \\
\text { irradiation } \\
\text { of phage } \\
\text { (min.) }\end{array}$} & \multirow[b]{2}{*}{$\begin{array}{l}\text { Dilution at } \\
\text { which the } \\
\text { preparation } \\
\text { was plated }\end{array}$} & \multicolumn{3}{|c|}{ Plates not exposed to visible light } & \multicolumn{3}{|c|}{$\begin{array}{l}\text { Plates exposed for } 3 \mathrm{hr} \text {. to dayligh } \\
\text { immediately after plating }\end{array}$} \\
\hline & & $\begin{array}{l}\text { Total nos. } \\
\text { of plaques } \\
\text { formed on } \\
4 \text { plates }\end{array}$ & $\begin{array}{l}\text { Proportion of } \\
\text { remaining } \\
\text { activity }\end{array}$ & $k^{*}$ & $\begin{array}{l}\text { Total nos. } \\
\text { of plaques } \\
\text { formed on } \\
4 \text { plates }\end{array}$ & $\begin{array}{l}\text { Proportion of } \\
\text { remaining } \\
\text { activity }\end{array}$ & $k^{*}$ \\
\hline 0 & $1 / 10^{7}$ & 165 & $1 \cdot 00$ & 一 & 158 & $1 \cdot 00$ & - \\
\hline $\mathbf{2 \cdot 2 5}$ & $1 / 10^{5}$ & 131 & $0 \cdot 0079$ & $2 \cdot 15$ & 336 & $0 \cdot 021$ & $1 \cdot 72$ \\
\hline $4 \cdot 5$ & $1 / 10^{3}$ & 130 & $0 \cdot 000079$ & $2 \cdot 10$ & 765 & $0 \cdot 00048$ & $1 \cdot 70$ \\
\hline
\end{tabular}

Table 5 shows that a smaller value of $k$ is obtained if the agar plates inoculated with mixtures of host bacteria and irradiated phage are exposed for some time to visible light than if they are kept all the time in darkness. In each condition, however, the value of $k$ is constant. The decrease in the value of $k$ arises from the fact that u.v. irradiated phage shows increased residual activity if the infected host bacteria are exposed to visible light. The phenomenon is shown by Rhizobium phage in all details as observed by Dulbecco (1950) with a number of coli phages and described as 'photoreactivation'. The constancy of $k$ under constant conditions of exposure to visible light or in its absence agrees with the so-called 'dose reduction prin- 
ciple' of Kelner (1949), according to which exposure to visible light is equivalent to reducing the dose of u.v. radiation by a constant factor. The principle was formulated for u.v. irradiated bacteria and found by Dulbecco (1950) to apply to u.v. irradiated coli phages and by Bawden \& Kleczkowski (1953) to some u.v. irradiated plant viruses.

Visible light increases the residual activity of u.v. irradiated phage preparations only if the infected host bacteria are exposed to it. Exposure of the irradiated phage preparations, or of the host bacteria, or of both, separately, i.e. before they are mixed, has no effect. Similarly, the residual activity of u.v. irradiated preparations of some plant viruses is increased by exposing the inoculated host plant to visible light, whereas exposure of irradiated virus preparations in vitro, or of the host plant before inoculation, has no such effect (Bawden \& Kleczkowski, 1953).

Visible light can counteract lethal and some other effects of u.v. radiation on unicellular (see Kelner, 1951) and on some multicellular (Bawden \& Kleczkowski, 1952) organisms by acting on them directly, whereas it can counteract comparable effects of u.v. radiation on bacteriophages and plant viruses only when they have combined with their cellular host organisms. Cellular structure is thus apparently essential for the occurrence of this phenomenon.

The fact that illumination of infected host bacteria cannot increase residual activity of u.v. irradiated phage above a certain limit, so that a proportion of phage particles will remain inactive irrespective of the amount of illumination, led Dulbecco (1950) to conclude that there are two different kinds of injury inflicted by u.v. radiation on phage particles: 'photoreactivable' and 'nonphotoreactivable'. The conclusion that there are at least two and possibly more different kinds of injury indeed seems inescapable. The fact that the value of $k$ is constant when the conditions of illumination are constant means that the process of inflicting each kind of injury is a separate first-order reaction. Conclusions that can be drawn from this are given elsewhere (Bawden \& Kleczkowski, 1953).

\section{Relative instability of active phage in irradiated preparations}

Tables 6 and 7 show that when u.v. irradiated and unirradiated phage preparations are incubated in identical conditions, the former lose their activity at a proportionally higher rate than the latter. The more a preparation is irradiated the higher is the relative rate of the decrease of its remaining activity (Table 6). The difference between irradiated and control preparations is noticeable when the incubation temperature is near $0^{\circ}$, but it becomes more obvious as the temperature increases, i.e. when both irradiated and control preparations become less stable (Table 7).

It is concluded that irradiated phage particles that still remain active are less stable than those in control preparations. Their relative instability does not result from the presence in the medium of any materials that are produced by u.v. radiation and are harmful to phage particles, because unirradiated phage preparations diluted in irradiated preparations are as stable as their 
controls. The instability is, therefore, a property of the irradiated phage particle and it is a result of either a change in the structure of the particle caused by u.v. radiation, or a selective effect of the radiation. The latter possibility seems unlikely, because it necessitates the assumption that the

Table 6. Effect of incubation at $34^{\circ}$ of preparations of phage 317 ultraviolet irradiated for various lengths of time

\begin{tabular}{|c|c|c|c|c|}
\hline \multirow[b]{2}{*}{$\begin{array}{l}\text { Time of } \\
\text { irradiation } \\
\quad \text { (min.) }\end{array}$} & \multirow[b]{2}{*}{$\begin{array}{l}\text { Dilution at which } \\
\text { the preparation } \\
\text { was plated }\end{array}$} & \multicolumn{2}{|c|}{$\begin{array}{l}\text { Numbers of plaques formed on } \\
4 \text { plates by samples plated }\end{array}$} & \multirow[b]{2}{*}{$\begin{array}{l}\text { Drop in } \\
\text { activity to }\end{array}$} \\
\hline & & $\begin{array}{l}\text { Immediately } \\
\text { after } \\
\text { irradiation }\end{array}$ & $\begin{array}{l}\text { After } 3 \mathrm{hr} . \\
\text { incubation at } \\
34^{\circ} \text { following } \\
\text { irradiation }\end{array}$ & \\
\hline 0 & $1 / 10^{z}$ & 305 & 295 & $97 \%$ \\
\hline $1 \cdot 75$ & $1 / 10^{8}$ & 84 & 60 & $71 \%$ \\
\hline $3 \cdot 5$ & $1 / 10^{4}$ & 225 & 74 & $33 \%$ \\
\hline $5 \cdot 0$ & $1 / 10^{2}$ & 980 & 257 & $26 \%$ \\
\hline
\end{tabular}

Table 7. Effect of incubating an ultraviolet irradiated preparation of 317 phage at different temperatures

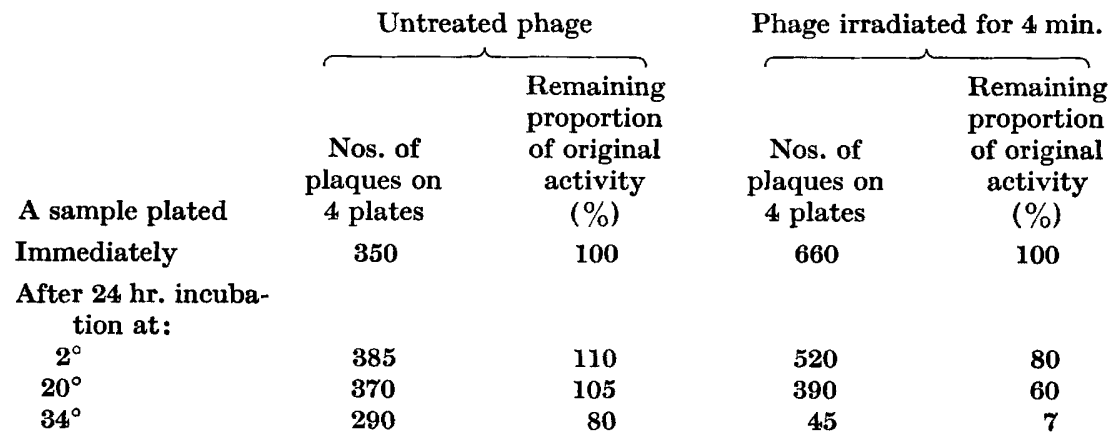

Samples of unirradiated phage preparation were plated at a dilution of $1 / 10^{7}$ and those of the irradiated preparation at $1 / 10^{3}$.

more stable particles are more easily inactivated by u.v. radiation than the less stable ones. Moreover, it would have to be assumed that phage particles differ in susceptibility to u.v. radiation, and this means that the value of $k$ should decrease as the residual activity of irradiated phage preparations decreases to the values reached in the experiments shown in Tables 6 and 7 , whereas in fact the value of $k$ remained approximately constant (Tables 4 and 5). It seems, therefore, more likely that u.v. radiation can so alter a phage particle that, although still active, it is rendered unstable.

The relative instability of particles that remain active after exposure to u.v. radiation is a phenomenon that does not seem to be limited to bacteriophages, for it has also been observed in preliminary experiments with trypsin (Kleczkowski, to be published). It was not observed with a few u.v. irradiated plant viruses that were tested (Bawden \& Kleczkowski, 1953), but the failure 
may have resulted from failure to adjust experimental conditions to the much greater stability of the viruses used.

Alper (1952) has just reported that inactivation of a phage by $X$-rays still goes on after the irradiation of its preparation has ended. Two different causes of this could be distinguished. In the first place $\mathrm{X}$-rays alter phage particles making them susceptible to the inactivating effect of hydrogen peroxide, and, secondly, X-rays produce hydrogen peroxide in the medium. Diluting irradiated phage in unirradiated medium can, therefore, prevent its further quick inactivation.

Instability of residual activity of u.v. irradiated preparations of the Rhizobium bacteriophages is not likely to be caused by a similar combination of two causes, for diluting the preparations $1 / 1000$ in unirradiated medium did not make them more stable. On the contrary, they even became less stable, suggesting the presence of some protective material in the crude bacterial lysate.

When residual activity of u.v. irradiated phage preparations falls as a result of ageing, the ability of the preparations to respond to exposure of infected host bacteria to visible light seems to remain unchanged. The ratio of the number of plaques formed with exposure to visible light to that formed without exposure does not seem to alter appreciably. It is concluded that irradiated phage particles that still are fully active and those active only if the infected host is exposed to visible light, both lose their activities at the same relative rate. The ability of an u.v. irradiated phage particle to be active only if the infected host is exposed to visible light may be a transition stage between fully active and fully inactive states, but there is no evidence for this.

\section{REFERENCES}

ALPER, T. (1952). A new after-effect of X-rays on dilute aqueous suspensions of bacteriophage. Nature, Lond. 169, 964.

Bawden, F. C. \& KleczKowski, A. (1952). Ultraviolet injury to higher plants counteracted by visible light. Nature, Lond. 169, 90.

Bawden, F. C. \& Kieczkowski, A. (1953). The behaviour of some plant viruses after exposure to ultraviolet radiation. J. gen. Microbiol. 8, 145.

BeDford, T. H. B. (1927). The nature of action of ultra-violet light on microorganisms. Brit. J. exp. Path. 8, 437.

Colbenz, W. W. \& Fulton, H. R. (1924). A radiometric investigation of the germicidal action of ultra-violet radiation. Sci. Pap. U.S. Bur. Stand. 19, 641.

Dulbecco, R. (1950). Experiments on photoreactivation of bacteriophages inactivated with ultraviolet radiation. J. Bact. 59, 329.

Henle, W. (1950). Interference phenomenon between animal viruses: a review. J. Immunol. 64, 203.

KelNer, A. (1949). Photoreactivation of ultraviolet treated Escherichia coli, with special reference to the dose-reduction principle and to ultraviolet-induced mutations. J. Bact. 58, 511.

KelNer, A. (1951). Action spectra for photoreactivation of ultraviolet-irradiated Escherichia coli and Streptomyces griseus. J. gen. Physiol. 34, 835.

Kueczkowska, L. (1945). The production of plaques by Rhizobium bacteriophage in poured plates and its value as a counting method. J. Bact. 50, 71 . 
KLeczkowski, J. \& Kleczkowskr, A. (1952). Effect of specific polysaccharides produced by the host bacteria and of ribonuclease on the multiplication of Rhizobium phages. J. gen. Microbiol. 7, 340.

Latarjet, R. \& Morenne, P. (1951). Inactivation d'un bacteriophage par un rayonnement ultra-violet de très faible intensité. Ann. Inst. Pasteur, 80, 220.

LatarJet, R. \& Wahl, R. (1945). Précisions sur l'inactivation des bacteriophages par les rayons ultraviolets. Ann. Inst. Pasteur, 71, 336.

Luria, S. E. \& Delbrück, M. (1942). Interference between inactivated bacterial virus and active virus of the same strain and of a different strain. Arch. Biochem. 1, 207.

Luria, S. E. \& Dulbecco, R. (1949). Genetic recombination leading to production of active bacteriophage from ultraviolet inactivated bacteriophage particles. Genetics, 34, 95.

Luria, S. E., Williams, R. C. \& Backus, R. C. (1951). Electron microscopic counts of bacteriophage particles. J. Bact. 61, 179.

Price, W. H. (1950). Phage formation in Staphylococcus muscae cultures. IX. Effect of multiple infection on virus synthesis in the absence and presence of specific substrates. J. gen. Physiol. 34, 251.

Proks, J. (1933). Recherches sur l'irradiation des milieux nutritifs bacteriologiques. Lait, 13, 331.

Wyss, O., Haas, F., Clark, J. B. \& Stone, W. S. (1950). Some effects of ultraviolet irradiation on micro-organisms. J. cell. comp. Physiol. 35, Suppl. no. 1, 133.

(Received 14. July 1952) 